\title{
(6) OPEN ACCESS \\ Novel myosin-based therapies for congenital cardiac and skeletal myopathies
}

\author{
Julien Ochala, ${ }^{1}$ Yin-Biao Sun ${ }^{2}$
}

${ }^{1}$ Centre of Human and Aerospace Physiological Sciences, King's College London, London, UK

${ }^{2}$ Randall Division of Cell and Molecular Biophysics, British Heart Foundation Centre of Research Excellence, King's College London, London, UK

\section{Correspondence to} Julien Ochala, Centre of Human \& Aerospace Physiological Sciences, Faculty of Life Sciences and Medicine, King's College London, Room 3.3, Shepherd's House, Guy's Campus, London SE1 1UL, UK julien.ochala@kcl.ac.uk

Received 29 April 2016 Accepted 15 June 2016 Published Online First 13 July 2016

CrossMark

To cite: Ochala J, Sun Y-B. J Med Genet 2016;53:651654

\section{ABSTRACT}

The dysfunction in a number of inherited cardiac and skeletal myopathies is primarily due to an altered ability of myofilaments to generate force and motion. Despite this crucial knowledge, there are, currently, no effective therapeutic interventions for these diseases. In this short review, we discuss recent findings giving strong evidence that genetically or pharmacologically modulating one of the myofilament proteins, myosin, could alleviate the muscle pathology. This should constitute a research and clinical priority.

In cardiac and skeletal muscles, the contractile machinery consists of assemblies of interdigitating myofilaments integrated in highly ordered entities termed sarcomeres. ${ }^{1}$ Mutations in genes encoding proteins located in the sarcomeres have been associated with various functional effects at the myofilament level grandly contributing to a wide range of clinical phenotypes such as hypertrophic cardiomyopathy (HCM), dilated cardiomyopathy (DCM), restrictive cardiomyopathy (RCM), nemaline myopathy or Laing early onset distal myopathy. ${ }^{2}{ }^{3}$ No treatment exists for these sarcomeric diseases. The current guidelines state that therapeutic interventions should simply target symptoms relief. ${ }^{4}$ The present short review article aims to briefly summarise the recent advances in our understanding of the molecular pathogenic mechanisms and the rationale for further testing myofilament-based therapeutic interventions involving the molecular motor, myosin.

\section{SARCOMERIC MUTATIONS AND CLINICAL PHENOTYPES}

Here, the focus is on congenital cardiomyopathies and skeletal myopathies caused by dominant inherited and de novo mutations in genes encoding sarcomeric proteins. Mutations in MYH7 and MYBPC3 encoding for $\beta$-myosin heavy chain and myosinbinding protein $\mathrm{C}$, respectively, are responsible for more than $70 \%$ of identified cardiac cases. ${ }^{5}$ Other genes such as MYL2, MYL3, ACTC1, TNNT2, TNNI3, TPM1, TTN and DES are also affected but account for less than 5\% each. ${ }^{5}$ These gene defects lead to HCM, which is associated with left ventricular hypertrophy, small cavity size and vigorous systolic function. ${ }^{6}$ They can also induce DCM, RCM and left ventricular non-compaction cardiomyopathy, which are also characterised by enlarged left ventricles but with various effects on systolic function. ${ }^{7-9}$ Skeletal muscle-related mutations have also been identified in many genes including $N E B$ and ACTA1 encoding for nebulin and skeletal $\alpha$-actin, respectively, as well as TPM2, TPM3, MYH7 and MYH2. ${ }^{10}{ }^{11}$ These mutations often interfere with the normal limb, masticatory and respiratory muscle functioning resulting in atrophy and impairing mobility, feeding and breathing. ${ }^{10} 11$ The following is a non-exhaustive list of the most common diseases: nemaline myopathy, ${ }^{11}$ Laing early onset distal myopathy, ${ }^{12}$ actin myopathy, ${ }^{13}$ intranuclear rod myopathy, ${ }^{13}$ rod-core disease, ${ }^{13}$ congenital fibretype disproportion, ${ }^{13}$ hyaline body myopathy, ${ }^{12}$ myosin storage myopathy, ${ }^{12}$ inclusion body myopathy ${ }^{12}$ and myofibrillar myopathy. ${ }^{14}$ Interestingly, a few of the above mutations, especially in the $\mathrm{MYH7}$ gene, are associated with cardiac and skeletal symptoms as the encoded protein, $\beta /$ slow-cardiac myosin is present in both cardiac and skeletal muscles. ${ }^{12}$

\section{HYPERCONTRACTILE OR HYPOCONTRACTILE MYOFILAMENTS}

All these proteins are essential for muscle contraction. Briefly, in the sarcomere, calcium ions activate the thin filaments by directly binding to troponin $\mathrm{C}$, allowing the movement of tropomyosin molecules to uncover myosin-binding sites on actin monomers. Myosin then binds and pulls on the thin filaments, shortening the sarcomere. Myosin cycling is triggered by the hydrolysis of ATP into ADP and inorganic phosphate. The release of phosphate is crucial for the myosin head-bending and force generation. Subsequently, when calcium ions are removed from the cytoplasm, the sarcomere relaxes. Other sarcomeric proteins such as titin, the intermediate filaments and Z-disc proteins are also important for mechanosensing and maintaining the sarcomeric structure during contraction. ${ }^{15}{ }^{16}$ When sarcomeric mutations occur, the genotypephenotype relationships become complex. Muscle dysfunction usually depends on the mutation location within the gene, the consequence at the protein level and the secondary disease-related protein post-translational modifications. ${ }^{2}{ }^{3}$ Mutant proteins or post-translational modifications of sarcomeric proteins in the presence of mutations alter troponin $\mathrm{C}$ activation, tropomyosin conformational changes, myosin enzymatic ATPase activity, ultimately altering the duty ratio, which is the fraction of myosin heads forming strong force-generating interactions with thin filaments at any moment. Increasing or decreasing the duty ratio modulates force production, shortening velocity, power output and energy cost. Since the power output is the product of force and velocity of muscle contraction, any modulation of force or/and velocity would lead to an alteration in power. These molecular alterations thus result in either myofilament hypercontractility or hypocontractility. ${ }^{3}{ }^{17}$ In the case of HCM and DCM mutations, these phenomena overall affect the cardiac output and 
can induce various abnormalities and remodelling in myocardial structure and function, ultimately provoking obstruction, heart failure and/or sudden death. For instance, M531R mutants in the motor domain of the human $\beta /$ slow-cardiac myosin molecule have been shown to be stronger motors and have been suggested to interrupt myosin head putative interactions with other proteins (eg, myosin-binding protein C) resulting in hyperdynamic heart. ${ }^{18}$ In contrast to congenital cardiomyopathies where a vast number of mutations have hypercontractile consequences, most of skeletal myopathies-related mutations induce hypocontractility and overall weakness, ${ }^{17}{ }^{19-21}$ with only a few exceptions contributing to muscle stiffness and/or hypertonia. 2223

\section{RATIONALE FOR MYOFILAMENT-ORIENTATED THERAPIES}

The current cardiac therapeutic interventions using small molecules have mixed long-term improvements on muscle pathology/ remodelling or clinical outcomes. One potential explanation is that these particular interventions do not directly target the molecular pathogenic causes of the muscle diseases, that is, myofilament dysfunction. Hence, developing new therapies that precisely correct for the contractile alteration may represent novel and efficacious approaches to preventing onset and progression or treating muscle pathology in the setting of inherited cardiac and skeletal myopathies. ${ }^{24}$ As myofilament activation requires the calcium ions, a few positive inotropes have been developed and subdivided into two categories, that is, calciummobilising agents and calcium sensitisers. ${ }^{26}$ These drugs could potentially increase myofilament function. ${ }^{26}$ Calcium-mobilising compounds, such as amrinone, milrinone and vesnarinone, act as phosphodiesterase 3 (PDE3) inhibitors and favour an increase in the amount of intracellular calcium ions released from the sarcoplasmic reticulum. Similarly, some of the calcium sensitisers, including levosimendan, a drug used in patients with heart failure, have some PDE3 inhibitory activity, but directly bind to troponin $\mathrm{C}$, decreasing the concentration of calcium ions required to trigger muscle contraction, increasing cardiac efficiency. ${ }^{27}$ This is notably the case of MCI-154, pimobendan, sulmazole and bepridil. ${ }^{28-31}$ The main advantage of this class of drugs over calcium-mobilising agents is the stimulation of the activity without increasing the cytosolic calcium concentration. However, all the above positive inotropes have been observed to aggravate the cardiac phenotypes and provoke arrhythmias, hypotension and mortality in a number of heart diseases such as HCM. A few other small molecules have specifically been developed for skeletal myopathies such as CK-2066206, CK-2127107 or tirasemtiv. ${ }^{19} 3233$ They specifically bind to the fast isoform of troponin $\mathrm{C}$ that is only present in skeletal myofilaments. Their clinical efficacy remains uncertain as they drastically slow the rate of calcium ions dissociation from troponin C, impairing the relaxation process. ${ }^{33}$

\section{MYOSIN AS A PREFERENTIAL TARGET}

In addition to troponin modulators, another recent experimental therapeutic approach consists of fine-tuning myosin function (table 1). The research compounds CGP-48506 and EMD-57033 directly affect myosin activity and the duty ratio $^{19}{ }^{34-36}$ but have been observed to be toxic. Omecamtiv mecarbil, on the other hand, has a potential for therapeutic application. $^{37}$ This strong positive inotropic small molecule binds directly to cardiac myosin and acts as an allosteric effector to enhance myosin motor activity and cardiac performance without increasing the intracellular calcium concentration. ${ }^{37}$ Omecamtiv mecarbil shifts the equilibrium of the myosin ATPase hydrolysis cycle towards products by accelerating phosphate release and leads to a faster transient from weak to strong actin-bound states ${ }^{38}$ (figure 1). Therefore, this drug exhibits the positive inotropic effects by increasing the duty ratio of myosin motor. In the heart, it prolongs the systolic ejection time without any increase in the rate of pressure development or myocardial oxygen demand. This shortens the diastolic filling time resulting in reduced coronary blood flow and risks of ischaemia. Clinical trials are encouraging and oral omecamtiv mecarbil could potentially be beneficial in the context of DCM and RCM where sarcomeric mutations reduce the myosin duty ratio. For HCM, negative inotropic agents are likely to have positive effects. Research molecules including blebbistatin and 2,3-butanedione monoxime have been developed and found to inhibit myosin activity by stabilising the myosin converter domain in a relaxed conformation, inducing a slowing of phosphate release and a decreasing in the duty ratio. ${ }^{39} 40$ Unfortunately, the toxicity of these small compounds is quite high. ${ }^{24}$ Recently, a small molecule, MYK-461, which also interferes with the phosphate release step of the myosin ATPase cycle, has been shown the potential of therapeutic approach for HCM. MYK-461 inhibits cardiac myosin ATPase by slowing

Table 1 Experimental approaches targeting myosin (derived from Ref. 24)

\begin{tabular}{|c|c|c|c|}
\hline Approach & Compound & Target & Function \\
\hline \multirow[t]{7}{*}{ Pharmacological } & Blebbistatin (research tool only) & $\begin{array}{l}\text { Myosin class II } \\
\text { All heavy chain isoforms }\end{array}$ & Inhibitor \\
\hline & $N$-benzyl- $p$-toluene sulphonamide (research tool only) & $\begin{array}{l}\text { Myosin class II } \\
\text { Fast-skeletal heavy chain isoform }\end{array}$ & Inhibitor \\
\hline & 2,3-butanedione monoxime (research tool only) & $\begin{array}{l}\text { Myosin class II } \\
\text { All heavy chain isoforms }\end{array}$ & Inhibitor \\
\hline & MYK-461 (preclinical-MyoKardia) & $\begin{array}{l}\text { Myosin class II } \\
\text { B/slow-cardiac heavy chain isoform }\end{array}$ & Inhibitor \\
\hline & Omecamtiv Mecarbil (clinical trial—Cytokinetics) & $\begin{array}{l}\text { Myosin class II } \\
\text { B/slow-cardiac heavy chain isoform }\end{array}$ & Activator \\
\hline & CGP48506 (preclinical-Novartis) & $\begin{array}{l}\text { Myosin class II } \\
\text { B/slow-cardiac heavy chain isoform }\end{array}$ & Activator \\
\hline & EMD57033 (preclinical-Merck) & $\begin{array}{l}\text { Myosin class II } \\
\text { B/slow-cardiac heavy chain isoform }\end{array}$ & Activator \\
\hline Genetic & MYL4 incorporation (preclinical) & $\begin{array}{l}\text { Myosin class II } \\
\text { Atrial/fetal essential light chain isoform }\end{array}$ & Activator \\
\hline
\end{tabular}




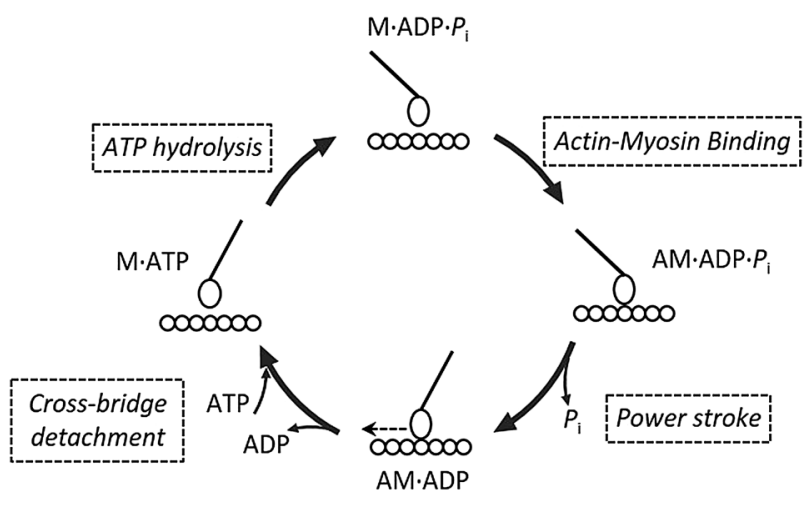

Figure 1 Schematic illustration showing actomyosin chemomechanical cycle. The transition from the weakly bound AM.ADP. $P_{\mathrm{i}}$ state to the strongly bound $A M \cdot A D P$ state is a key and rate-limiting step in the entire cycle that involves the release of $\mathrm{P}_{\mathrm{i}}$ from the active site. Many myosin-base therapeutic or experimental interventions are targeting this step, for example, myosin activator (omecamtiv mecarbil) and inhibitors (MYK-461, blebbistatin, 2,3-butanedione monoxime, $N$-benzyl- $p$-toluene sulphonamide) in table 1. A, actin; AM, actomyosin complex; $M$, myosin.

phosphate release and, consequently, reduces the myosin duty ratio and power output (figure 1). Tests on transgenic mice mimicking HCM and expressing particular mutations in the gene encoding for $\beta$-myosin heavy chain (leading to point substitutions: R403Q, R719W and R453C) demonstrate that MYK-461 reduces cardiac contractility and, when administered early in the course of the disease, it blunts the development of left ventricular hypertrophy. ${ }^{41}$ These phenomena are cardiacspecific and MYK-461 has no impact on skeletal muscle function. ${ }^{41}$

Modulating the activation of myosin molecules in the context of skeletal myopathies can be achieved using gene therapy. Each myosin molecule is composed of two regulatory and two essential/alkali light chains. ${ }^{42}$ These latter are regulating the duty ratio, ${ }^{42}$ with some of the isoforms being very efficient force generators. This is specifically the case of the isoform encoded by the MYL4 gene and only present in the heart and skeletal muscles from embryos. ${ }^{42}$ By implementing this isoform in the skeletal muscles of mice carrying one specific mutation in the ACTA1 gene encoding for skeletal $\alpha$-actin ( $\mathrm{H} 40 \mathrm{Y}$ replacement), myosin activity is enhanced and myofibres recover their force production, avoiding the development of muscle atrophy. ${ }^{43}$

\section{CONCLUSION}

By alleviating muscle pathology, myosin activators and inhibitors represent promising new drug targets. Indeed, at the molecular level, these modify the ATPase activity, phosphate release, myosin-binding state and duty ratio, which are essential for regulating the force generation.

Funding $\mathrm{JO}$ is supported by a grant from the Medical Research Council, UK (MR/N002768/1). Y-BS is supported by the British Heart Foundation.

Competing interests None declared.

Provenance and peer review Commissioned; externally peer reviewed.

Open Access This is an Open Access article distributed in accordance with the terms of the Creative Commons Attribution (CC BY 4.0) license, which permits others to distribute, remix, adapt and build upon this work, for commercial use, provided the original work is properly cited. See: http://creativecommons.org/licenses/ by/4.0/

\section{REFERENCES}

1 Schiaffino S, Reggiani C. Fiber types in mammalian skeletal muscles. Physiol Rev 2011;91:1447-531.
2 Laing NG, Nowak KJ. When contractile proteins go bad: the sarcomere and skeletal muscle disease. Bioessays 2005:27:809-22.

3 van der Velden J, Ho CY, Tardiff JC, Olivotto I, Knollmann BC, Carrier L. Research priorities in sarcomeric cardiomyopathies. Cardiovasc Res 2015;105:449-56.

4 Gersh BJ, Maron BJ, Bonow RO, Dearani JA, Fifer MA, Link MS, Naidu SS, Nishimura RA, Ommen SR, Rakowski H, Seidman CE, Towbin JA, Udelson JE, Yancy CW, American College of Cardiology Foundation/American Heart Association Task Force on Practice G, American Association for Thoracic $S$, American Society of $E$, American Society of Nuclear C, Heart Failure Society of A, Heart Rhythm S, Society for Cardiovascular A, Interventions, Society of Thoracic S. 2011 ACCF/AHA guideline for the diagnosis and treatment of hypertrophic cardiomyopathy: executive summary: a report of the American College of Cardiology Foundation/American Heart Association Task Force on Practice Guidelines. Circulation 2011;124:2761-96.

5 Ho CY, Charron P, Richard P, Girolami F, Van Spaendonck-Zwarts KY, Pinto Y. Genetic advances in sarcomeric cardiomyopathies: state of the art. Cardiovasc Res 2015; 105:397-408.

6 Lopes LR, Rahman MS, Elliott PM. A systematic review and meta-analysis of genotype-phenotype associations in patients with hypertrophic cardiomyopathy caused by sarcomeric protein mutations. Heart 2013;99:1800-11.

7 Chang AN, Potter JD. Sarcomeric protein mutations in dilated cardiomyopathy. Heart Fail Rev 2005; 10:225-35.

8 Parvatiyar MS, Pinto JR, Dweck D, Potter JD. Cardiac troponin mutations and restrictive cardiomyopathy. J Biomed Biotechnol 2010;2010:350706.

9 Uchiyama T, Yoshimura K, Kaneko K, Nemoto S, Ichida F, Hata Y, Nishida N. Surgical repair of left ventricular noncompaction in a patient with a novel mutation of the myosin heavy chain 7 gene. Tohoku J Exp Med 2012;228:301-4.

10 Romero NB, Clarke NF. Congenital myopathies. Handb Clin Neurol 2013;113:1321-36

11 Romero NB, Sandaradura SA, Clarke NF. Recent advances in nemaline myopathy. Curr Opin Neurol 2013;26:519-26.

12 Tajsharghi $\mathrm{H}$, Oldfors A. Myosinopathies: pathology and mechanisms. Acta Neuropathol 2013;125:3-18.

13 Nowak KJ, Ravenscroft G, Laing NG. Skeletal muscle $\alpha$-actin diseases (actinopathies): pathology and mechanisms. Acta Neuropathol 2013;125:19-32.

14 Claeys KG, Fardeau M. Myofibrillar myopathies. Handb Clin Neurol 2013:113:1337-42.

15 Gautel M. The sarcomeric cytoskeleton: who picks up the strain? Curr Opin Cell Biol 2011;23:39-46.

16 Gautel M, Djinović-Carugo K. The sarcomeric cytoskeleton: from molecules to motion. J Exp Biol 2016:219:135-45.

17 Ochala J. Thin filament proteins mutations associated with skeletal myopathies: defective regulation of muscle contraction. J Mol Med 2008;86:1197-204.

18 Spudich JA. The myosin mesa and a possible unifying hypothesis for the molecular basis of human hypertrophic cardiomyopathy. Biochem Soc Trans 2015;43:64-72.

19 Ochala J, Gokhin DS, Pénisson-Besnier I, Quijano-Roy S, Monnier N, Lunardi J, Romero NB, Fowler VM. Congenital myopathy-causing tropomyosin mutations induce thin filament dysfunction via distinct physiological mechanisms. Hum Mol Genet 2012;21:4473-85.

20 Ochala J, Lehtokari VL, Iwamoto $\mathrm{H}$, Li M, Feng HZ, Jin JP, Yagi N, Wallgren-Pettersson C, Penisson-Besnier I, Larsson L. Disrupted myosin cross-bridge cycling kinetics triggers muscle weakness in nebulin-related myopathy. FASEB J 2011:25:1903-13.

21 Ottenheijm CA, Lawlor MW, Stienen GJ, Granzier H, Beggs AH. Changes in cross-bridge cycling underlie muscle weakness in patients with tropomyosin 3-based myopathy. Hum Mol Genet 2011;20:2015-25.

22 Jain RK, Jayawant S, Squier W, Muntoni F, Sewry CA, Manzur A, Quinlivan R, Lillis S, Jungbluth H, Sparrow JC, Ravenscroft G, Nowak KJ, Memo M, Marston SB, Laing NG. Nemaline myopathy with stiffness and hypertonia associated with an ACTA1 mutation. Neurology 2012;78:1100-3.

23 Lindqvist J, Pénisson-Besnier I, Iwamoto H, Li M, Yagi N, Ochala J. A myopathy-related actin mutation increases contractile function. Acta Neuropathol 2012;123:739-46.

24 Hwang PM, Sykes BD. Targeting the sarcomere to correct muscle function. Nat Rev Drug Discov 2015;14:313-28.

25 Tardiff JC, Carrier L, Bers DM, Poggesi C, Ferrantini C, Coppini R, Maier LS Ashrafian $\mathrm{H}$, Huke $\mathrm{S}$, van der Velden J. Targets for therapy in sarcomeric cardiomyopathies. Cardiovasc Res 2015;105:457-70.

26 Ochala J. Ca2+ sensitizers: An emerging class of agents for counterbalancing weakness in skeletal muscle diseases? Neuromuscul Disord 2010;20:98-101.

27 Kitada Y, Kobayashi M, Narimatsu A, Ohizumi Y. Potent stimulation of myofilament force and adenosine triphosphatase activity of canine cardiac muscle through a direct enhancement of troponin C Ca++ binding by $\mathrm{MCl}-154$, a novel cardiotonic agent. J Pharmacol Exp Ther 1989;250:272-7.

28 Papp Z, Édes I, Fruhwald S, De Hert SG, Salmenperä M, Leppikangas H, Mebazaa A, Landoni G, Grossini E, Caimmi P, Morelli A, Guarracino F, Schwinger RH, Meyer S, Algotsson L, Wikström BG, Jörgensen K, Filippatos G, Parissis JT, González MJ, Parkhomenko A, Yilmaz MB, Kivikko M, Pollesello P, Follath F. Levosimendan: 
molecular mechanisms and clinical implications: consensus of experts on the mechanisms of action of levosimendan. Int J Cardiol 2012;159:82-7.

29 Boyle KL, Leech E. A review of the pharmacology and clinical uses of pimobendan. J Vet Emerg Crit Care (San Antonio) 2012;22:398-408.

30 van Meel JC, Zimmermann R, Diederen W, Erdman E, Mrwa U. Increase in calcium sensitivity of cardiac myofibrils contributes to the cardiotonic action of sulmazole. Biochem Pharmacol 1988;37:213-20.

31 Kischel $P$, Stevens $L$, Mounier Y. Differential effects of bepridil on functional properties of troponin $\mathrm{C}$ in slow and fast skeletal muscles. Br J Pharmacol 1999:128:767-73.

32 de Winter JM, Buck D, Hidalgo C, Jasper JR, Malik Fl, Clarke NF, Stienen GJ, Lawlor MW, Beggs AH, Ottenheijm CA, Granzier H. Troponin activator augments muscle force in nemaline myopathy patients with nebulin mutations. J Med Genet 2013;50:383-92.

33 Russell AJ, Hartman JJ, Hinken AC, Muci AR, Kawas R, Driscoll L, Godinez G, Lee KH, Marquez D, Browne WFT, Chen MM, Clarke D, Collibee SE, Garard M, Hansen R, Jia Z, Lu PP, Rodriguez H, Saikali KG, Schaletzky J, Vijayakumar V, Albertus DL, Claflin DR, Morgans DJ, Morgan BP, Malik Fl. Activation of fast skeletal muscle troponin as a potential therapeutic approach for treating neuromuscular diseases. Nat Med 2012;18:452-5.

34 Palmer S, Di Bello S, Davenport SL, Herzig JW. The novel inotropic agent CGP 48506 alters force primarily by $\mathrm{Ca}(2+)$-independent mechanisms in porcine skinned trabeculae. Cardiovasc Res 1996;32:411-21.

35 Ochala J, Radell PJ, Eriksson LI, Larsson L. EMD 57033 partially reverses ventilator-induced diaphragm muscle fibre calcium desensitisation. Pflugers Arch 2010:459:475-83.
36 Solaro RJ, Gambassi G, Warshaw DM, Keller MR, Spurgeon HA, Beier N, Lakatta EG. Stereoselective actions of thiadiazinones on canine cardiac myocytes and myofilaments. Circ Res 1993;73:981-90.

37 Malik FI, Hartman JJ, Elias KA, Morgan BP, Rodriguez H, Brejc K, Anderson RL, Sueoka SH, Lee KH, Finer JT, Sakowicz R, Baliga R, Cox DR, Garard M, Godinez G, Kawas R, Kraynack E, Lenzi D, Lu PP, Muci A, Niu C, Qian X, Pierce DW, Pokrovskii M, Suehiro I, Sylvester S, Tochimoto T, Valdez C, Wang W, Katori T, Kass DA, Shen YT, Vatner SF, Morgans DJ. Cardiac myosin activation: a potential therapeutic approach for systolic heart failure. Science 2011;331:1439-43.

38 Liu Y, White HD, Belknap B, Winkelmann DA, Forgacs E. Omecamtiv Mecarbil modulates the kinetic and motile properties of porcine $\beta$-cardiac myosin. Biochemistry 2015;54:1963-75.

39 McKillop DF, Fortune NS, Ranatunga KW, Geeves MA. The influence of 2,3-butanedione 2-monoxime (BDM) on the interaction between actin and myosin in solution and in skinned muscle fibres. J Muscle Res Cell Motil 1994;15:309-18.

40 Limouze J, Straight AF, Mitchison T, Sellers JR. Specificity of blebbistatin, an inhibitor of myosin II. J Muscle Res Cell Motil 2004;25:337-41.

41 Green EM, Wakimoto H, Anderson RL, Evanchik MJ, Gorham JM, Harrison BC, Henze M, Kawas R, Oslob JD, Rodriguez HM, Song Y, Wan W, Leinwand LA, Spudich JA, McDowell RS, Seidman JG, Seidman CE. A small-molecule inhibitor of sarcomere contractility suppresses hypertrophic cardiomyopathy in mice. Science 2016;351:617-21.

42 Gordon AM, Homsher E, Regnier M. Regulation of contraction in striated muscle. Physiol Rev 2000;80:853-924.

43 Lindqvist J, Levy Y, Pati-Alam A, Hardeman EC, Gregorevic P, Ochala J. Modulating myosin restores muscle function in a mouse model of nemaline myopathy. Ann Neurol 2016. 